\title{
Australian Journal of Crop Science \\ Enzymatic activity, gas exchange and production of soybean co-inoculated with Bradyrhizobium japonicum and Azospirillum brasilense
}

\author{
Lucas Guilherme Bulegon ${ }^{1^{*}}$, Vandeir Francisco Guimarães ${ }^{1}$, Jeferson Klein ${ }^{2}$, Andre Gustavo \\ Battistus $^{1}$, Adriano Mitio Inagaki ${ }^{1}$, Luiz Claudio Offemann ${ }^{1}$, Aline Kelly Pomini de Souza ${ }^{1}$
}

\author{
${ }^{1}$ Agricultural Sciences Center, Parana Western State University-UNIOESTE, Pernambuco Street, 1777, Box 91, \\ Zip Code: 85960-000, Marechal Cândido Rondon - PR, Brazil \\ ${ }^{2}$ Professor, Doutor, UNOPAR Av. Rocha Pombo - Pacaembu, Zip Code: 85816-540, Cascavel - PR, Brazil
}

\author{
*Correponding author: lucas_bulegon@yahoo.com.br
}

\begin{abstract}
Soybean occupies a prominent place in the national scenario, and the search for new technologies is continuous. Thus, this study aimed to evaluate the co-inoculation, through seeds, from diazotrophs bacteria of genus Bradyrhizobium japonicum and Azospirillum brasilense, and its effects against the nodulation, enzyme activity, gas exchange, and soybean production. The experiment was conduced in completely randomized design, with seven treatments and four replications. Seven treatments were constituted in the control (no nitrogen fertilization and seed inoculation); application of $\mathrm{N}$ mineral; seed inoculation with B. japonicum and A. brasilense AbV5+AbV6 and AbV5+AbV6+AbV7 strains and their co-inoculations. The evaluations were performed in V4 and R4 stages, with particular biometric characteristics of shoots and roots, the gas exchange indices of the leaves and the activity of peroxidase and phenylalanine ammonia lyase enzymes. Also in the R9 stage were determined components of production and production per plant culture. The results indicate that, when combining two species of bacteria through seeds have limitation in nodulation. The $A$. brasilense, strains AbV5+AbV6+AbV7, inoculated through seed promotes increase in nodulation from the natural soil population; it still raises the activity of plant defense enzymes in V4 stage, however, reduces the photosynthetic rate per foliar unit. Nitrogen fertilization, seed inoculation with B. japonicum, A. brasilense (AbV5+AbV6+AbV7) and A. brasilense (AbV5+AbV6+AbV7) $+B$. japonicum, provide the highest yields per plant. It has been observed even though the dry mass of root and aerial part have a direct influence on plant production, and a negative relation between stomatal conductance and the number of nodules in the growing season, and that photosynthesis does not influence the plant's production, just its production factors.
\end{abstract}

Keywords: Glycine $\max \mathrm{L}$; co-inoculation; biological nitrogen fixation; bacteria that promote plant growth; enzymes of plant protection; photosynthesis

Abbreviations: RDM_Root dry matter; NN_number of nodules per plant; DMN_dry matter of nodules per plant; LA_leaf area, DMAP_dry matter of aerial part; PAL_Phenylalanine ammonia lyase; POX_peroxidase activity; $A_{-} \mathrm{CO}_{2}$ net assimilation rate; $E_{-}$ transpiration; $g_{s \_}$stomatal conductance; NP_Number of pods per plant; NSP_number of seeds per pod; PROD_production.

\section{Introduction}

Originating from Southeast China, soybean (Glycine max (L.) Merrill), is the most widely grown oilseed in the world. In Brazil its expansion took place from the 60 s, leading the country to be the second largest grain producer, reached in the 2013/2014 harvest larger volume of 86,000 tonnes (Conab, 2014). It can be stated that this expansion is directly linked to the genetic improvement associated with the selection of strains of nitrogen-fixing bacteria (NFB), parallel to technological development. In the $60 \mathrm{~s}$ the selection of genotypes was directly related to responsive cultivars to nitrogen mineral fertilizers, possibly linked to high protein levels observed in the grains of these cultivars, requiring about $240 \mathrm{~kg} \mathrm{ha}^{-1}$ of $\mathrm{N}$ to achieve average production of $3,000 \mathrm{~kg} \mathrm{ha}^{-1}$ (Hungria et al., 2001). However, the requirement of high $\mathrm{N}$ has become limiting due to the high cost of production of mineral fertilizers attributed to the large expenditure of energy from oil, besides the great environmental impact. After the discovery of NFB process with responsive strains, and associated with the selection of cultivars susceptible to interaction, Brazilian soy began to dispense mineral fertilizer, representing a significant reduction in production costs (Pedrosa and Souza, 2008). Currently, diazotrophic bacteria that present best increments for culture belong to the genus Bradyrhizobium. This microorganism group can join the plan forming nodules on their roots (Cassán et al., 2009). Moreover, they possess the ability to break the triple bond of atmospheric nitrogen dioxide $\left(\mathrm{N}_{2}\right)$ which is not used by plants, changing it into a form available to vegetables (Taiz and Zeiger, 2013). This process meets all need to nitrogen plant, eliminating the mineral fertilizer (Silva et al., 2011).

However, the energy expenditure of the bacteria in this process is high and there is the possibility that the bacteria not performing it in the presence of certain mineral $\mathrm{N}$ content in the soil by reducing the affinity for oxygen of leghemoglobin (Deninson and Harter, 1995). Therefore, there is a search for news ways to improve the efficient use of nitrogen along the development and production of soybeans. 
Among the various genus of diazotrophic bacteria, the genus Azospirillum deserves attention because it consists of bacteria that, besides the NFB, are known to produce or stimulate the production of compounds for plant growth promoters. Some of these compounds have already been observed being produced by the interaction between the plant and microorganism, such as auxin, 3-indoleacetic acid (IAA) (Crozier et al., 1988), cytokinins (Cacciari et al., 1989), gibberellic acid (Bottini et al., 1989), and other indole compounds (Crozier et al., 1988).

It is known that increasing the amount of such compounds can help in the development of plants, especially in the production of grains (Figueiredo et al., 2010; Araujo et al., 2012). Thus, larger root systems were observed in soybean plants which received inoculated seeds (Ferlini, 2006; Bárbaro et al. 2009) and higher nodulation (Anollés, 1997; Fei and Vessey, 2004). It was also noted increases in gas exchange in wheat plants (Rodrigues et al., 2012), enzyme stimulation (Reis Junior et al., 2008) and increase in chlorophyll content (Quadros et al., 2014).

In this context, the present study aimed to evaluate the inoculation and co-inoculation diazotrophic bacteria of genus Azospirillum and Bradyrhizobium, and their effects across the nodulation, enzyme activity, photosynthesis, and soybean production.

\section{Results and discussion}

\section{Plant growth}

Considering the dry mass of roots (Table 1), treatment with the addition of mineral $\mathrm{N}$ was higher in both evaluations compared to the other treatments. Based on this result, it can be deduced that the greatest expansion and dry matter of the root system when fertilized with mineral $\mathrm{N}$ may be related to better use available via $\mathrm{N}$ fertilization. Therefore it is known that $\mathrm{N}$ is easily moved by irrigation at greater depthsthere is root growth of the plants to perform its absorption (Araujo et al., 2005). When considering the treatments that received inoculation, these did not present large variations regarding the control. However, Ferlini et al. (2006), noted an increase for this variable when soybeans were co-inoculated with $B$. japonicum and A. brasilense, in Argentina. The same authors observed increments of up to $200 \%$ dry matter in root systems, however failed to link this fact to the higher crop yield.

Regarding the number of nodules per plant, the treatment that received only nitrogen source was inferior in both assessments (V4 and R4) (Table 1). There was a reduction in the number of nodules per plant performed when nitrogen fertilization $90.5 \%$ and $81.4 \%$ compared to plants inoculated with A. brasilense, AbV5+AbV6+AbV7 strains, in V4 stage and R4 respectively. In V4 stage treatment with inoculation of $A$. brasilense, AbV5+AbV6+AbV7 strains, as well as the co-inoculation of $B$. japonicum $+A$. brasilense (AbV5+AbV6) were greater, not differing from the control and plants whose seeds were inoculated with $A$. brasilense, $\mathrm{AbV} 5+\mathrm{AbV} 6+\mathrm{AbV} 7+$ B. japonicum. In the R4 stage the same treatments remained higher, also standing out the plants inoculated via seeds with A. brasilense, AbV5+AbV6 strains. For dry mass of nodules (Table 1) the results were similar to the number of nodules per plant due to the correlation between the variables amounted to $r=0.709$ and $r=0.771$ $\mathrm{V} 4$ in R4 ( $\mathrm{p}<0.05)$, the same correlation positive was reported by Valadão et al. (2009). These results make it possible to highlight the effect of A. brasilense in cell elongation as mentioned in working by Lemos et al. (2013), and production of root hairs (Radwan et al., 2004). This results in an increase in places for bacteria infection and consequent formation of nodules, since these begin their formation from the root (Taiz and Zieger, 2013), contributing to increase in nodulation.

The lower nodulation in plants that received nitrogen fertilization occurs due to inhibition of biological nitrogen fixation (Van Kessel and Hartley, 2000). According Deninson and Harter (1995), this effect is due to reduced oxygen availability in nodular breath as Stefens and Neyra (1983), attributed the result to limiting carbohydrates to the nodule metabolism. Most nodulation observed in plants inoculated with $A$. brasilense can only be attributed to the presence of $B$. japonicum in the substrate, as evidenced by nodulation occurred in not inoculated plants with $B$. japonicum (control).

Another factor leading to the increase in nodule number and nodule dry weight per plant is linked to the production of phytohormones by bacteriasince the level of auxins and cytokinins is determinant for nodulation (Van Kessel and Hartley, 2000), with auxin being the main hormone produced and secreted by $A$. brasilense (Crozier et al., 1988).

The plants that received $\mathrm{N}$ in $\mathrm{V} 4$ growth stage had higher average values of leaf area (LA), following the increase already reported in RDM, compared to the other treatments (Table 2). However, in R4, Brad+AbV5+AbV6 coinoculation treatment stood out having greater LA compared to control, nitrogen, B. japonicum, AbV5+AbV6+AbV7 and $\mathrm{Brad}+\mathrm{AbV} 5+\mathrm{AbV} 6+\mathrm{AbV7}$. This co-inoculation, surpassed treatment with inoculation of B. japonicum isolated in $75.40 \%$ in $\mathrm{R} 4$, the discrepancy of values at this stage was confirmed by the weak and not significant correlation obtained. To the dry mass of aerial part in both stages evaluated the supply of $\mathrm{N}$ promoted the highest average. This increase in foliage and dry mass of aerial part is related to the growth-promoting effect by the A. brasilense, this being the result of better hormonal balance, further exploration by the root system and better use of productive resources. As for the highest averages of $\mathrm{N}$ that was due to higher rate of absorption, incorporation and accumulation in the plant, when compared to the inoculations provided.

\section{Enzymatic activity and chlorophyll}

Evaluating the enzymatic activity it was observed for peroxidase (POX) (Table 2) that plants derived from inoculation and co-inoculation with AbV5+AbV6+AbV7 showed greater activity in V4, significant difference was not observed in R4. This enzyme participates in various processes of relevant importance in plant metabolism, primarily related to defense mechanisms. And actively participate in lignification process by oxidation of phenolic compounds, it is important agent in the IAA oxidation (Baysal et al., 2003), a hormone produced by A. brasilense. Worth remembering that treatments using AbV5+AbV6+AbV7 promoted high nodulation, whether represented by number of nodules or nodules of dry matter. When assessing the phenylalanine ammonia lyase (PAL) (Table 2), the results followed the pattern shown for POX, showing that in V4 treatments that received inoculation with A. brasilense showed greater activity of this enzyme, but not differing from control and plants that received $\mathrm{N}$ fertilization. Were not observed significant differences in PAL on R4 stage of culture.

PAL has an important role in secondary metabolism participating in the formation of various phenylpropanol 
Table 1. Root dry matter (RDM), number of nodules per plant (NN) and dry matter of nodules per plant (DMN), leaf area (LA) and dry matter of aerial part (DMAP) of soybean plants submitted to inoculation and co-inoculation with diazotrophic bacteria, as assessed in V4 and R4 stages of this culture. Marechal Cândido Rondon-PR, 2012.

\begin{tabular}{|c|c|c|c|c|c|c|}
\hline \multirow[t]{2}{*}{ Treatments } & \multicolumn{2}{|l|}{$\begin{array}{l}\text { RDM } \\
\left(\text { g plant }^{-1}\right)\end{array}$} & \multicolumn{2}{|l|}{$\mathrm{NN}$} & \multicolumn{2}{|l|}{$\begin{array}{l}\text { DMN } \\
\left(\text { g plant }^{-1}\right)\end{array}$} \\
\hline & V4 & R4 & V4 & R4 & V4 & R4 \\
\hline Control & $0.74_{ \pm 0.13} \mathrm{~b}$ & $3.69_{ \pm 0.11} \mathrm{~b}$ & $46.25_{ \pm 3,62} \mathrm{ab}$ & $58.63_{ \pm 5.19} \mathrm{a}$ & $0.11_{ \pm 0.02} \mathrm{bc}$ & $1.14_{ \pm 0.03} \mathrm{ab}$ \\
\hline Nitrogen & $1.26_{ \pm 0.21} \mathrm{a}$ & $6.25_{ \pm 0.31} \mathrm{a}$ & $5.25_{ \pm 0.41} \mathrm{~d}$ & $10.17_{ \pm 1.42} \mathrm{c}$ & $0.03_{ \pm 0.006} \mathrm{c}$ & $0.21_{ \pm 0.04} \mathrm{~d}$ \\
\hline B. japonicum & $0.57_{ \pm 0.05} \mathrm{~b}$ & $3.05_{ \pm 0.22} \mathrm{~b}$ & $31.28_{ \pm 1.86} \mathrm{c}$ & $38.67_{ \pm 2.74} \mathrm{~b}$ & $0.13_{ \pm 0.01} \mathrm{bc}$ & $0.71_{ \pm 0.13} \mathrm{bc}$ \\
\hline $\mathrm{AbV} 5+\mathrm{AbV} 6$ & $0.60_{ \pm 0.07} \mathrm{~b}$ & $1.87_{ \pm 0.10} \mathrm{c}$ & $34.67_{ \pm 3.31} \mathrm{bc}$ & $54.67_{ \pm 2.98} \mathrm{a}$ & $0.23_{ \pm 0.01} \mathrm{a}$ & $0.68_{ \pm 0.03} \mathrm{c}$ \\
\hline $\mathrm{AbV} 5+\mathrm{AbV} 6+\mathrm{AbV7}$ & $0.77_{ \pm 0.09} \mathrm{~b}$ & $2.93_{ \pm 0.20} \mathrm{bc}$ & $55.38_{ \pm 2.17} \mathrm{a}$ & $54.60_{ \pm 2.14} \mathrm{a}$ & $0.19_{ \pm 0.01} \mathrm{ab}$ & $1.40_{ \pm 0.13} \mathrm{a}$ \\
\hline $\mathrm{Brad}+\mathrm{AbV} 5+\mathrm{AbV} 6$ & $0.75_{ \pm 0.05} \mathrm{~b}$ & $2.93_{ \pm 0.26} \mathrm{bc}$ & $54.00_{ \pm 1.51} \mathrm{a}$ & $46.69_{ \pm 1.55} \mathrm{ab}$ & $0.17_{ \pm 0.03} \mathrm{ab}$ & $1.02_{ \pm 0.08} \mathrm{abc}$ \\
\hline $\mathrm{Brad}+\mathrm{AbV} 5+\mathrm{AbV} 6+\mathrm{AbV7}$ & $0.85_{ \pm 0.05} \mathrm{~b}$ & $3.68_{ \pm 0.14} \mathrm{~b}$ & $46.33_{ \pm 2.87} \mathrm{ab}$ & $35.94_{ \pm 3.62} \mathrm{~b}$ & $0.18_{ \pm 0.008} \mathrm{ab}$ & $1.03_{ \pm 0.04} \mathrm{abc}$ \\
\hline C.V. $(\%)$ & 16.14 & 13.92 & 14.68 & 17.86 & 28.39 & 22.25 \\
\hline D.M.S. & 0.30 & 1.15 & 13.17 & 13.77 & 0.10 & 0.45 \\
\hline $\mathrm{F}$ & $12.6 * *$ & $31.59 * *$ & $36.92 * *$ & $25.78 * *$ & $9.71 * *$ & $15.44 * *$ \\
\hline \multirow{2}{*}{ Treatments } & \multirow{2}{*}{\multicolumn{3}{|c|}{$\begin{array}{r}\mathrm{LA}\left(\mathrm{cm}^{2}\right) \\
\mathrm{R} 4\end{array}$}} & & & \\
\hline & & & & V4 & \multicolumn{2}{|c|}{$\mathrm{R} 4$} \\
\hline Control & $15.32_{ \pm 2.32} \mathrm{~cd}$ & \multicolumn{2}{|c|}{$291.15_{ \pm 3.71} \mathrm{c}$} & $1.75_{ \pm 0.10} \mathrm{~b}$ & \multicolumn{2}{|c|}{$21.90_{ \pm 0.16} \mathrm{~b}$} \\
\hline Nitrogen & $48.96_{ \pm 0.2 .67} \mathrm{a}$ & \multicolumn{2}{|c|}{$476.95_{ \pm 10.86} \mathrm{~b}$} & $2.98_{ \pm 0.24} \mathrm{a}$ & \multicolumn{2}{|c|}{$34.50_{ \pm 0.29} \mathrm{a}$} \\
\hline B. japonicum & $7.43_{ \pm 0.33} \mathrm{~d}$ & \multicolumn{2}{|c|}{$334.90_{ \pm 12.50} \mathrm{c}$} & $1.43_{ \pm 0.07} \mathrm{~b}$ & \multicolumn{2}{|c|}{$23.39_{ \pm 0.58}^{ \pm b}$} \\
\hline $\mathrm{AbV} 5+\mathrm{AbV} 6$ & $13.28_{ \pm 0.70} \mathrm{~d}$ & \multicolumn{2}{|c|}{$491.46_{ \pm 31.50} \mathrm{ab}$} & $1.70_{ \pm 0.08} \mathrm{~b}$ & \multicolumn{2}{|c|}{$22.72_{+0.43} \mathrm{~b}$} \\
\hline $\mathrm{AbV} 5+\mathrm{AbV} 6+\mathrm{AbV7}$ & $23.04_{ \pm 1.16} \mathrm{cb}$ & \multicolumn{2}{|c|}{$361.14_{ \pm 11.80} \mathrm{c}$} & $1.97_{ \pm 0.11}^{ \pm b}$ & \multicolumn{2}{|c|}{$23.96_{+0.57} \mathrm{~b}$} \\
\hline $\mathrm{Brad}+\mathrm{AbV} 5+\mathrm{AbV} 6$ & $24.13_{ \pm 1.06} \mathrm{~b}$ & \multicolumn{2}{|c|}{$587.41_{+33.3 \mathrm{a}} \mathrm{a}$} & $1.91_{ \pm 0.07} \mathrm{~b}$ & \multicolumn{2}{|c|}{$23.39_{+074} \mathrm{~b}$} \\
\hline $\mathrm{Brad}+\mathrm{AbV} 5+\mathrm{AbV} 6+\mathrm{AbV7}$ & $21.94_{ \pm 0.34} \mathrm{bc}$ & \multicolumn{2}{|c|}{$392.33_{+20.35} \mathrm{bc}$} & $2.07_{ \pm 0.008} \mathrm{~b}$ & \multicolumn{2}{|c|}{$22.44_{ \pm 0.18} \mathrm{~b}$} \\
\hline C.V. $(\%)$ & 15.75 & \multicolumn{2}{|c|}{11.29} & 14.14 & \multicolumn{2}{|c|}{10.48} \\
\hline D.M.S. & 7.97 & \multicolumn{2}{|c|}{108.87} & 0.64 & \multicolumn{2}{|c|}{5.93} \\
\hline $\mathrm{F}$ & $59.06 * *$ & \multicolumn{2}{|c|}{$19.16^{*}$} & $12.28 * *$ & \multicolumn{2}{|c|}{$11.70 * *$} \\
\hline
\end{tabular}

* and **, significant at 5 and $1 \%$, respectively by the $\mathrm{F}$ test. Averages followed by the same lowercase letter in the column do not statistically differ from each other by Tukey test $(\mathrm{p} \leq 0.05) . \pm$ standard error of the mean

Table 2. Phenylalanine ammonia lyase (PAL), peroxidase activity (POX) and Chlorophyll of soybean plants submitted to inoculation and co-inoculation with diazotrophic bacteria in the V4 stage and R4 culture. Marechal Cândido Rondon-PR, 2012.

\begin{tabular}{|c|c|c|c|c|}
\hline \multirow[t]{2}{*}{ Treatments } & \multicolumn{2}{|c|}{$\begin{array}{l}\text { POX } \\
\left(\mathrm{UA} \mathrm{min}^{-1} \mathrm{mg} \text { protein }\right. \\
\end{array}$} & \multicolumn{2}{|c|}{$\begin{array}{l}\text { PAL } \\
\text { (mg of mg trans-cinnamic acid } \\
\mathrm{h}^{-1} \mathrm{mg} \mathrm{protein}^{-1} \text { ) }\end{array}$} \\
\hline & V4 & $\mathrm{R} 4$ & V4 & $\mathrm{R} 4$ \\
\hline Control & $0.075_{ \pm 0.002} \mathrm{c}$ & $0.109_{ \pm 0.002}$ & $2.168_{ \pm 0.079} \mathrm{ab}$ & $1.505_{ \pm 0.086}$ \\
\hline Nitrogen & $0.098_{ \pm 0.002} \mathrm{c}$ & $0.137_{ \pm 0.001}$ & $1.710_{ \pm 0.056} \mathrm{ab}$ & $1.621_{ \pm 0.107}$ \\
\hline B. japonicum & $0.154_{ \pm 0.001} \mathrm{ab}$ & $0.114_{ \pm 0.007}^{ \pm .007}$ & $1.493_{ \pm 0.173} \mathrm{~b}$ & $1.793_{ \pm 0.039}$ \\
\hline $\mathrm{AbV} 5+\mathrm{AbV} 6$ & $0.110_{ \pm 0.003} \mathrm{bc}$ & $0.131_{ \pm 0.005}$ & $2.224_{ \pm 0.047} \mathrm{a}$ & $1.634_{ \pm 0.134}$ \\
\hline $\mathrm{AbV} 5+\mathrm{AbV} 6+\mathrm{AbV7}$ & $0.162_{ \pm 0.014} \mathrm{a}$ & $0.148_{ \pm 0.017}^{ \pm 0.00}$ & $2.126_{ \pm 0.169} \mathrm{ab}$ & $1.815_{ \pm 0.079}^{ \pm 0.154}$ \\
\hline $\mathrm{Brad}+\mathrm{AbV} 5+\mathrm{AbV} 6$ & $0.063_{ \pm 0.004} \mathrm{c}$ & $0.154_{ \pm 0.013}$ & $1.613_{ \pm 0.066} \mathrm{ab}$ & $1.939_{ \pm 0.226}$ \\
\hline $\mathrm{Brad}+\mathrm{AbV} 5+\mathrm{AbV6}+\mathrm{AbV7}$ & $0.162_{ \pm 0.018} \mathrm{a}$ & $0.150_{ \pm 0.013}$ & $1.579_{ \pm 0.218} \mathrm{ab}$ & $1.592_{ \pm 0.079}$ \\
\hline C.V. $(\%)$ & 17.75 & 17.90 & 16.57 & 16.45 \\
\hline D.M.S. & 0.048 & 0.055 & 0.703 & 0.642 \\
\hline $\mathrm{F}$ & $16.13 * *$ & $2.20^{\mathrm{ns}}$ & $4.33^{* *}$ & $1.18^{\mathrm{ns}}$ \\
\hline \multirow{2}{*}{ Treatments } & \multicolumn{2}{|c|}{ Chlorophyll $a\left(\mathrm{mg} \mathrm{g}^{-1}\right)$} & \multicolumn{2}{|c|}{ Chlorophyll $b\left(\mathrm{mg} \mathrm{g}^{-1}\right)$} \\
\hline & V4 & R4 & $\mathrm{V} 4$ & R4 \\
\hline Control & $0.0013_{ \pm 0.0001} \mathrm{a}$ & $0.047_{ \pm 0.002} \mathrm{~d}$ & $0.0012_{ \pm 0.0001} \mathrm{ab}$ & $0.064_{ \pm 0.012} \mathrm{bc}$ \\
\hline Nitrogen & $0.0013_{ \pm 0.0001} \mathrm{a}$ & $0.158_{ \pm 0.034} \mathrm{c}$ & $0.0011_{ \pm 0.0003} \mathrm{abc}$ & $0.028_{ \pm 0.011} \mathrm{c}$ \\
\hline B. japonicum & $0.0014_{ \pm 0.0001} \mathrm{a}$ & $0.279_{ \pm 0.053} \mathrm{~b}$ & $0.0014_{ \pm 0.0001} \mathrm{a}$ & $0.178_{ \pm 0.011} \mathrm{~b}$ \\
\hline AbV5+AbV6 & $0.0013_{ \pm 0.0002} \mathrm{a}$ & $0.371_{ \pm 0.038} \mathrm{ab}$ & $0.0009_{ \pm 0.0002} \mathrm{bc}$ & $0.177_{ \pm 0.031} \mathrm{~b}$ \\
\hline $\mathrm{AbV} 5+\mathrm{AbV} 6+\mathrm{AbV7}$ & $0.0014_{ \pm 0.0001} \mathrm{a}$ & $0.292_{ \pm 0.062} \mathrm{~b}$ & $0.0013_{ \pm 0.0002} \mathrm{ab}$ & $0.146_{ \pm 0.087} \mathrm{bc}$ \\
\hline $\mathrm{Brad}+\mathrm{AbV} 5+\mathrm{AbV} 6$ & $0.0014_{ \pm 0.0001} \mathrm{a}$ & $0.452_{ \pm 0.037} \mathrm{a}$ & $0.0013_{ \pm 0.0001} \mathrm{ab}$ & $0.053_{ \pm 0.023} \mathrm{bc}$ \\
\hline $\mathrm{Brad}+\mathrm{AbV} 5+\mathrm{AbV} 6+\mathrm{AbV7}$ & $0.0007_{ \pm 0.0001}^{ \pm b}$ & $0.197_{ \pm 0.032} \mathrm{c}$ & $0.0007_{ \pm 0.0001} \mathrm{c}$ & $0.231_{ \pm 0.082} \mathrm{a}$ \\
\hline C.V. $(\%)$ & 11.32 & 19.35 & 16.78 & 24.42 \\
\hline D.M.S. & 0.0003 & 0.10 & 0.0004 & 0.127 \\
\hline $\mathrm{F}$ & $11.49 * *$ & $39.76 * *$ & $6.67 * *$ & $135.12 * *$ \\
\hline
\end{tabular}

$*$ and **, significant at 5 and $1 \%$, respectively by the $\mathrm{F}$ test. Averages followed by the same lowercase letter in the column do not statistically differ from each other by Tukey test $(\mathrm{p} \leq 0.05)$. 
Table 3. $\mathrm{CO}_{2}$ net assimilation rate $(A)$, transpiration $(E)$ and stomatal conductance $(g s)$ of soybean plants submitted to inoculation and co-inoculation with diazotrophic bacteria in the V4 stage and R4 culture. Marechal Cândido Rondon-PR, 2012.

\begin{tabular}{|c|c|c|c|c|c|c|}
\hline \multirow{2}{*}{ Treatments } & \multicolumn{2}{|c|}{$A\left(\mu \mathrm{mol} \mathrm{m} \mathrm{m}^{-2} \mathrm{~s}^{-1}\right)$} & \multicolumn{2}{|c|}{$E\left(\mathrm{mmol} \mathrm{m}^{-2} \mathrm{~s}^{-1}\right)$} & \multicolumn{2}{|c|}{$g_{s}\left(\mathrm{~mol} \mathrm{~m}^{-2} \mathrm{~s}^{-1}\right)$} \\
\hline & V4 & $\mathrm{R} 4$ & $\mathrm{V4}$ & $\mathrm{R} 4$ & $\mathrm{~V} 4$ & $\mathrm{R} 4$ \\
\hline Control & $19.66_{ \pm 0.70} \mathrm{a}$ & $18.48_{ \pm 0.56} \mathrm{a}$ & $4.04_{ \pm 0.23}$ & $4.08_{ \pm 0.15}$ & $0.22_{ \pm 0.011} \mathrm{a}$ & $0.19_{ \pm 0.007} \mathrm{a}$ \\
\hline Nitrogen & $17.53_{ \pm 0.26} \mathrm{ab}$ & $16.28_{ \pm 0.52} \mathrm{ab}$ & $4.62_{ \pm 0.21}$ & $3.91_{ \pm 0.16}$ & $0.22_{ \pm 0.014} \mathrm{a}$ & $0.15_{ \pm 0.003} \mathrm{ab}$ \\
\hline B. japonicum & $16.47_{ \pm 0.82}^{ \pm 0 b}$ & $14.51_{ \pm 7.25} \mathrm{~b}$ & $4.03_{ \pm 0.07}^{ \pm 0.21}$ & $3.63_{ \pm 1.82}$ & $0.18_{ \pm 0.004}^{-0.014} \mathrm{ab}$ & $0.15_{ \pm 0.07} \mathrm{ab}$ \\
\hline AbV5+AbV6 & $16.64_{ \pm 0.71}^{ \pm 0.0 b}$ & $14.45_{ \pm 0.13} \mathrm{~b}$ & $3.91_{ \pm 0.17}$ & $3.70_{ \pm 0.14}$ & $0.16_{ \pm 0.004} \mathrm{~b}$ & $0.15_{ \pm 0.004} \mathrm{ab}$ \\
\hline $\mathrm{AbV} 5+\mathrm{AbV} 6+\mathrm{AbV7}$ & $14.46_{ \pm 0.78} \mathrm{~b}$ & $16.48_{ \pm 0.83} \mathrm{ab}$ & $3.79_{ \pm 0.29}$ & $3.84_{ \pm 0.24}$ & $0.13_{ \pm 0.006} \mathrm{~b}$ & $0.16_{ \pm 0.007} \mathrm{ab}$ \\
\hline $\mathrm{Brad}+\mathrm{AbV} 5+\mathrm{AbV} 6$ & $15.18_{ \pm 0.78} \mathrm{~b}$ & $15.92_{ \pm 0.56} \mathrm{ab}$ & $4.05_{ \pm 0.23}$ & $3.88_{ \pm 0.21}$ & $0.17_{ \pm 0.011} \mathrm{ab}$ & $0.16_{ \pm 0.01} \mathrm{ab}$ \\
\hline $\mathrm{Brad}+\mathrm{AbV} 5+\mathrm{AbV} 6+\mathrm{AbV7}$ & $17.60_{ \pm 0.56} \mathrm{ab}$ & $15.97_{ \pm 0.62} \mathrm{ab}$ & $3.79_{ \pm 0.15}$ & $3.62_{ \pm 0.17}$ & $0.15_{ \pm 0.008} \mathrm{~b}$ & $0.13_{ \pm 0.005} \mathrm{~b}$ \\
\hline C.V $(\%)$ & 9.45 & 8.92 & 11.93 & 11.33 & 13.50 & 12.07 \\
\hline D.M.S & 3.65 & 3.28 & 1.10 & 0.99 & 0.03 & 0.043 \\
\hline $\mathrm{F}$ & $4.67 * *$ & $3.60 *$ & $1.38^{\mathrm{ns}}$ & $0.60^{\mathrm{ns}}$ & $9.54 * *$ & $3.19^{*}$ \\
\hline
\end{tabular}

* and **, significant at 5 and $1 \%$, respectively by the $\mathrm{F}$ test. Averages followed by the same lowercase letter in the column do not statistically differ from each other by Tukey test $(\mathrm{p} \leq 0.05)$.

Table 4. Number of pods per plant (NP), number of seeds per pod (NSP) and production (PROD) of soybean plants submitted to inoculation and co-inoculation with diazotrophic bacteria. Marechal Cândido Rondon-PR, 2012.

\begin{tabular}{|c|c|c|c|}
\hline Treatments & NP & NSP & $\begin{array}{l}\text { PROD } \\
\text { (g/plant) }\end{array}$ \\
\hline Control & $52.00_{ \pm 0.46} \mathrm{ab}$ & $2.95_{ \pm 0.10}$ & $24.20_{ \pm 0.72} \mathrm{bc}$ \\
\hline Nitrogen & $57.69_{ \pm 2.81} \mathrm{ab}$ & $2.85_{ \pm 0.09}$ & $33.03_{ \pm 1.19} \mathrm{a}$ \\
\hline B. japonicum & $58.44_{ \pm 2.34}$ a & $2.78_{ \pm 0.04}$ & $28.51_{ \pm 1.33} \mathrm{ab}$ \\
\hline $\mathrm{AbV} 5+\mathrm{AbV} 6$ & $48.47_{ \pm 0.83} \mathrm{abc}$ & $2.68_{ \pm 0.18}$ & $22.74_{ \pm 0.93} \mathrm{c}$ \\
\hline $\mathrm{AbV} 5+\mathrm{AbV} 6+\mathrm{AbV7}$ & $56.41_{ \pm 1.17} \mathrm{ab}$ & $2.75_{ \pm 0.05}$ & $28.40_{ \pm 0.98} \mathrm{ab}$ \\
\hline $\mathrm{Brad}+\mathrm{AbV} 5+\mathrm{AbV} 6$ & $45.83_{ \pm 2.13} \mathrm{bc}$ & $2.73_{ \pm 0.05}$ & $23.62_{ \pm 0.78} \mathrm{bc}$ \\
\hline $\mathrm{Brad}+\mathrm{AbV} 5+\mathrm{AbV6}+\mathrm{AbV7}$ & $39.17_{ \pm 4.11} \mathrm{c}$ & $2.90_{ \pm 0.06}^{ \pm 0.05}$ & $28.56_{ \pm 0.52} \mathrm{ab}$ \\
\hline C.V $(\%)$ & 10.47 & 7.83 & 8.23 \\
\hline D.M.S & 12.25 & 0.50 & 5.11 \\
\hline $\mathrm{F}$ & $7.11 * *$ & $0.82^{\mathrm{ns}}$ & $10.86 * *$ \\
\hline
\end{tabular}

$*$ and **, significant at 5 and $1 \%$, respectively by the $\mathrm{F}$ test. Averages followed by the same lowercase letter in the column do not statistically differ from each other by Tukey test $(\mathrm{p} \leq 0.05)$.

Table 5. Person correlation matrix for soybean plants variables submitted to inoculation and co-inoculation with diazotrophic bacteria.Marechal Cândido Rondon-PR, 2012.

\begin{tabular}{|c|c|c|c|c|c|c|c|c|c|c|c|c|c|c|c|}
\hline \multicolumn{16}{|c|}{ Stage V4 } \\
\hline & Clo a & Clo b & A & gs & E & NP & NSP & PRO & NN & LA & RDM & DMN & DMAP & POX & PAL \\
\hline Clo a & 1.000 & & & & & & & & & & & & & & \\
\hline Clo b & $0.847 *$ & 1.000 & & & & & & & & & & & & & \\
\hline A & -0.363 & -0.354 & 1.000 & & & & & & & & & & & & \\
\hline gs & 0.209 & 0.173 & 0.725 & 1.000 & & & & & & & & & & & \\
\hline $\mathrm{E}$ & 0.289 & 0.180 & 0.276 & $0.787 *$ & 1.000 & & & & & & & & & & \\
\hline NP & 0.739 & $0.712^{*}$ & -0.118 & 0.342 & 0.472 & 1.000 & & & & & & & & & \\
\hline NSP & -0.493 & -0.220 & $0.804 *$ & 0.54 & 0.193 & -0.112 & 1.000 & & & & & & & & \\
\hline PRO & -0.017 & 0.0006 & 0.002 & 0.175 & 0.526 & -0.423 & 0.319 & 1.000 & & & & & & & \\
\hline NN & -0.077 & 0.100 & -0.318 & -0.607 & $-0.838^{*}$ & -0.458 & -0.104 & -0.61 & 1.000 & & & & & & \\
\hline LA & -0.054 & -0.132 & 0.006 & 0.335 & $0.739 *$ & 0.145 & 0.189 & 0.651 & -0.545 & 1.000 & & & & & \\
\hline RDM & -0.184 & -0.202 & 0.197 & 0.433 & $0.745^{*}$ & 0.135 & 0.396 & $0.727 *$ & -0.594 & $0.971 *$ & 1.000 & & & & \\
\hline DMN & -0.130 & -0.242 & -0.047 & $-0.828 *$ & $-0.866^{*}$ & -0.537 & -0.577 & -0.0675 & $0.709^{*}$ & -0.619 & -0.721 & 1.000 & & & \\
\hline DMAP & -0.162 & -0.248 & 0.101 & 0.345 & $0.722 *$ & 0.111 & 0.206 & $0.686^{*}$ & -0.595 & $0.988 * *$ & $0.986^{* *}$ & -0.626 & 1.000 & & \\
\hline POX & -0.038 & $-0.185^{*}$ & -0.289 & -0.623 & -0.472 & 0.063 & -0.046 & 0.439 & 0.077 & -0.233 & -0.168 & 0.252 & -0.164 & 1.000 & \\
\hline PAL & 0.273 & -0.069 & 0.115 & -0.059 & -0.244 & 0.127 & -0.114 & -0.448 & 0.217 & -0.0165 & -0.200 & 0.296 & -0.142 & -0.170 & 1.000 \\
\hline \multicolumn{16}{|c|}{ Stage R4 } \\
\hline & Clo a & Clo b & A & gs & $\mathrm{E}$ & NP & NSP & PRO & NN & LA & RDM & DMN & DMAP & POX & PAL \\
\hline Clo a & 1.000 & & & & & & & & & & & & & & \\
\hline Clo b & -0.366 & 1.000 & & & & & & & & & & & & & \\
\hline A & -0.624 & 0.134 & 1.000 & & & & & & & & & & & & \\
\hline gs & -0.207 & -0.683 & 0.741 & 1.000 & & & & & & & & & & & \\
\hline $\mathrm{E}$ & -0.245 & -0.062 & $0.837^{*}$ & $0.893^{* *}$ & 1.000 & & & & & & & & & & \\
\hline NP & 0.015 & -0.712 & 0.009 & 0.444 & 0.274 & 1.000 & & & & & & & & & \\
\hline NSP & $-0.946 * *$ & 0.322 & 0.735 & 0.262 & 0.380 & -0.107 & 1.000 & & & & & & & & \\
\hline PRO & -0.406 & 0.140 & -0.005 & -0.268 & -0.118 & 0.423 & 0.327 & 1.000 & & & & & & & \\
\hline NN & 0.232 & -0.093 & 0.172 & 0.434 & 0.136 & -0.193 & -0.221 & $0.830 *$ & 1.000 & & & & & & \\
\hline LA & 0.682 & -0.170 & -0.389 & -0.343 & -0.061 & -0.321 & -0.576 & -0.184 & -0.245 & 1.000 & & & & & \\
\hline RDM & -0.553 & -0.076 & 0.378 & 0.061 & 0.364 & 0.294 & 0.576 & $0.792 *$ & $-0.837 *$ & -0.015 & 1.000 & & & & \\
\hline DMN & 0.021 & 0.204 & 0.396 & 0.302 & 0.129 & -0.279 & 0.578 & -0.430 & $0.771^{*}$ & -0.344 & -0.548 & 1.000 & & & \\
\hline DMAP & -0.143 & -0.313 & 0.017 & -0.042 & 0.228 & 0.465 & 0.055 & $0.755^{*}$ & $-0.859^{*}$ & 0.282 & $0.858 *$ & -0.738 & 1.000 & & \\
\hline POX & 0.386 & 0.334 & -0.153 & -0.473 & -0.213 & -0.480 & 0.099 & 0.122 & -0.175 & 0.630 & 0.007 & 0.193 & 0.125 & 1.000 & \\
\hline PAL & $0.824 *$ & -0.279 & -0.405 & -0.175 & -0.185 & 0.123 & -0.315 & -0.096 & 0.089 & 0.466 & -0.328 & 0.219 & -0.092 & 0.470 & 1.000 \\
\hline
\end{tabular}

* and **, significant at 1\%. Clo a: chlorophyll A; Clo b: chlorophyll B; A: photosynthesis; E: transpirATION; gs: stomatal conductance; NP: number of pods; NSP: número de grãos por vagem; PRO: production; NN: number of nodules; LA: leaf area; RDM: root dry matter; DMN: dry matter of nodules; DMAP: dry matter of aerial part; POX: peroxidase; PAL: Phenylalanine ammonia-lyase. 
compounds, flavonoids and phytoalexins able to act directly against some pathogens (Gerasimova et al., 2005).

The average values of POX found in this work agree with those found by Marques et al. (2012), working with potassium deficit in soybean plants. They also report that the values found between V5 and V7 culture were 0.2 and 0.6 UA $\min ^{-1} \mathrm{mg}$ protein ${ }^{-1}$, respectively, when the plants are nutritionally balanced. According to the authors, PAL values decrease with advancing age of the plant, a result similar to the values found in this study when considered absolute averages only.

In works developed by Almeida et al. (2012), reported that the longer the duration of exposure of plants over the action of microorganisms greater the activity of the POX and PAL, while plants that do not suffer from this action does not have variation.

The amount of chlorophyll found in the treatment $\mathrm{Brad}+\mathrm{AbV} 5+\mathrm{AbV} 6+\mathrm{AbV7}$, in the initial stage (V4) was 0.7 $\mu \mathrm{g} \mathrm{g}^{-1}$ being lower than the other treatments, with a reduction of at least $85.7 \%$ and $100 \%$ (Table 2). In R4 this treatment also had lower middle, but surpassing the control, and equating to treatment with $\mathrm{N}$. When observed the chlorophyll $b$, the behavior was similar in V4 resulting in lower average by Brad+AbV5+AbV6+AbV7. However R4 in the treatment of Brad+ AbV5+AbV6+AbV7 was superior to the others, with gain compared to control of $261 \%$. This increased value can be related to the plant input in the reproductive stage (R4), where this plant starts to have a greater demand for photosynthate and therefore a higher chlorophyll content. Such behavior has been described by Whitmarsh (2000), which justified the correlation between the physical process of absorption and conversion of physical energy of light into chemical energy.

This fact evidenced demonstrates the potential of $\mathrm{AbV} 5+\mathrm{AbV} 6+\mathrm{AbV7}$, especially in the reproductive phase and associated with $B$. japonicum in producing chlorophyll type $b$. Similarly, the association between $\mathrm{AbV} 5+\mathrm{AbV6}+\mathrm{AbV7}$, and as for the first two isolated response was not positive, so it can be AbV7 may be interfering with the performance of the plant.

\section{Gas exchange}

The average values of $\mathrm{CO}_{2}$ net assimilation rate (A) obtained in V4 show better photosynthetic performance of control in relation to plants inoculated with AbV5+AbV6+AbV7 and Brad+AbV5+AbV6. Similarly, in step R4, the values of (A) exceeded the control plant leaves which received inoculation with AbV5+AbV6 and B. japonicum (Table 3). This may be linked to the plant-bacterium interaction from the inoculation, since the presence of nodules in these plants is the result of natural population of $B$. japonicum in this substrate. Thus, non-inoculated soybean plants do not require energy consumption.

Thus, the lower photosynthetic rate obtained in V4 stage for the treatments that received AbV5 $+\mathrm{AbV} 6+\mathrm{AbV7}$, is probably connected with high root nodulation, where it can possibly provide intense competition for assimilated carbon, which has reduced the photosynthetic efficiency. In this sense, a research conducted by Fagan et al. (2007), reported that plants that fix nitrogen consume on average 11-13\% more carbon fixed a day for breath compared to plants supplied by nitrogen, justifying the results. This increase occurs by the increase of production dependent on carbon compounds as ureides and flavonoids (Flores et al., 2010; Juge et al., 2012).
In stage R4, while the other treatments decreased the photosynthetic rate in absolute terms, those who have received $\mathrm{AbV} 5+\mathrm{AbV} 6+\mathrm{AbV7}$ in an isolated way on the seed have demonstrated an increase, related to the effect of $A$. brasilense in maintaining green plant for longer due the greater presence of chlorophyll in the plant tissue, an effect demonstrated by Quadros et al. (2014), when studied the chlorophyll content in corn genotypes inoculated with different strains of $A$. brasilense. Increases in photosynthesis of soybean plants are reported by Kaschuk et al. (2009), when studied the same co-inoculation of the present study.

For leaf transpiration rate $(E)$, there were no significant differences between treatments, evidencing that variations in stomatal conductance were not enough to affect water loss by plants in these conditions.

When analyzed stomatal conductance $\left(g_{s}\right)$ the behavior was similar to $A$ (Table 4), initially showing superiority of control treatments, mineral N, B. japonicum and Brad+AbV5+AbV6 with superiority of $69.2 \%, 69.2 \%, 38.5 \%$ and $30.7 \%$ compared to AbV5+AbV6+AbV7, respectively. These results agree with those found by Konrad et al. (2005), when studying the gas exchange in the coffee culture. These authors report close relation between these two variables $(A$ and $g_{s}$ ). The same relation is still found by Costa and Marenco (2007) in the culture of andiroba.

The reduction in stomatal conductance according to Oliveira et al. (2005), is indicative of stress, particularly hydric in the plant, and other like low solar radiation and the exposure angle of the leaves to sunlight. The gas values found agree on those cited for different crops such as coffee (Konrad et al., 2005), buriti (Calbo and Moraes, 1997), bean (Oliveira et al., 2005) and soybean (Kaschuk et al., 2009). These are considered suitable by these authors for the development of the cultures in question. The same happened in the present study, allowing an adequate water balance and transpiration, which favors the photosynthetic activity.

\section{Soybean production}

For the production of components (Table 4) stands out inoculation with $A$. brasilense isolated and co-inoculated with B. japonicum, as $\mathrm{AbV} 5+\mathrm{AbV} 6+\mathrm{AbV7}$, promoting result equal to the treatment with mineral $\mathrm{N}$ and $B$. japonicum. Possibly this result is related to better utilization of water and consequently greater availability of photoassimilates for formation and development of crop grain.

The smaller pods numbers obtained in co-inoculations of $\mathrm{Brad}+\mathrm{AbV} 5+\mathrm{AbV} 6$ and Brad+AbV5+AbV6+AbV7 presented averages of $27.5 \%$ and $49.2 \%$ lower compared to the B. japonicum, respectively. Such reductions can result from competition during the infection process between the strains used, not achieving the ideal per plant population for each strain, resulting in a lower availability of $\mathrm{N}$ in the formation of pods, condition reported by Plazinsk \& Rolfe (1985), where the use of different bacteria in seed inoculation may result in interspecific inhibition during colonization by competition process.

When assessing the yield per plant it is noted that the treatments that received $\mathrm{AbV} 5+\mathrm{AbV} 6+\mathrm{AbV7}$ isolated or coinoculated showed results equal to control, nitrogen and $B$. japonicum. Lower absolute values were observed for AbV5+AbV6 isolated or co-inoculated, not differing only from control, with a down of $45.25 \%$ and $39.8 \%$ compared to $\mathrm{N}$, respectively. The production by the $B$. japonicum and $\mathrm{AbV} 5+\mathrm{AbV} 6+\mathrm{AbV} 7$ associate itself with the larger grain filling reported by Didonet et al. (2000), which allowed 
inoculation best translocation throughout the plant biomass, resulting in higher grain mass.

The results corroborate with Barbaro et al. (2009), where different forms of nitrogen fertilization and inoculation with $B$. japonicum and $A$. brasilense in soy, providing higher yields when performed co-inoculation and utilization of $B$. japonicum separately. However, the results in the literature are different, and to Santos et al. (2011), working under field conditions in two different regions of Paraná, studying coinoculations with $\mathrm{AbV} 5+\mathrm{AbV} 6+\mathrm{AbV7}$ and B. japonicum, found no significant differences in number of pods per plant and productivity of treatments.

\section{Correlation analysis}

When determining the correlation coefficients among the variables in their respective phenological stages and production components, it was observed in V4, positive correlation coefficient between the levels of chlorophyll $a$ and $b$. This result was expected since both are produced in large quantities because it is a photoassimilates accumulation phase and is completely dependent on the soybean plant photosynthesis to its maintenance. It was also found that in V4 photosynthesis already interferes in the productive characteristics of soybean, and found that the increase in photosynthetic rate correlates to large number of grains per pod on the plant. This condition occurs due to greater availability of reserves accumulated by the plant during its growing season, coupled with the photosynthetic activity at the moment, thus having a more homogeneous grain filling with lower abortion and incomplete formation of grains. In R4 stage the correlation between these two variables was not significant, but was high $(\mathrm{r}=0.735)$, showing that photosynthesis has great importance in the formation and grain filling in soybean plant. The absence of significant correlation between the photosynthetic rate and the actual plant for production is explained by intensive breeding program, which aimed to select the most stable cultivars in relation to light due to less sunlight in some producing regions. Another point that explains the absence of significant correlation is mentioned by Pereira (1989), where there is only correlation between $A$ and production in cultures that have leaves as economic interest body, not happening for those where fruits and grains are marketed.

The correlation obtained for $E$ and $g s$ in V4 and R4 is given by the physiology of the plant during the photosynthesis process, since the stomatal conductance and transpiration are dependent variables (Taiz and Zeiger, 2013) and when $E$ rises the plant is with open stomata, thereby resulting in greater loss of water.

It was also observed in V4 that $g s$ and DMN have negative correlation. This answer suggests a possible stomatal control in soybean plants in the activity of the nodules, as reports show that a number close to 30 viable nodules are sufficient for the plant (Fagan et al., 2007), as well as under field conditions usually this number is greater, as found in this study. In this condition occurs stomatal closure thus reducing the $\mathrm{CO}_{2}$ entrance by stomata and limiting water uptake by the roots. It notes that the node in the NFB is dependent on the photosynthetic activity, and the amount of photoassimilated limiting for the formation of $\mathrm{NH}_{4}$ in the nodule is reduced, maximizing conversion of $\mathrm{NH}_{4}$ to $\mathrm{NH}_{3}$ which can be incorporated through amino acids.

When considering the R4 stage, the need for $\mathrm{N}$ from NFB in the nodule is greater due to the higher number of physiological drains. Thus, this can not control is required and the correlation turns out not to be significant. This fact is proved when it finds that $E$ that was positively correlated to the gs as well showed a negative correlation with DMN and NN. E as well correlated positively in V4 with LA, RDM and DMAP, showing that at this stage, the greater the mass and the surface of the plant larger will be its loss of water due to increased absorption capacity of the root system, higher accumulation capacity in upper leaf surface and greater exposure to the solar rays that cause transpiration. In the R4 stage $E$ did not correlate with any of the variables, possibly due to statistical similarity between treatments for the DMAP values that phenophase.

The RDM was positively correlated with the PRO, LA and DMAP in V4 and the PRO and DMAP in R4. This result shows that the root system of culture has great importance in the development of aerial part reflecting production. From these results it can be inferred that the increase in productivity found in treatments inoculated with the strains AbV5+AbV6+AbV7 isolated or co-inoculated with $B$. japonicum is connected to the growth-promoting effect of the root system (Ferlini, 2006; Cassán et al., 2009) and aerial part (Lemos et al., 2013; Rodrigues et al., 2014) mainly having less weight the other factors, as these were the only significant correlations with production in both phenophases evaluated. The results of this study agree with mentioned by Dalchiavon and Carvalho (2012), who found positive correlations of mass increase the plant with the soybean crop productivity.

The activity of the enzymes studied exerts no influence on plant development, gas exchange and production, not being observed significant correlation effect (Table 5). Negative correlation was obtained from POX with chlorophyll $b$ in V4. However, this was weak, showing no great influence. The PAL correlated positively and strongly with the chlorophyll $a$ in the R4.

In according to the present results it can be inferred that the isolated inoculation $\mathrm{AbV} 5+\mathrm{AbV} 6+\mathrm{AbV7}$ has favored $B$. japonicum naturally present in the substrate, allowing increased nodulation on soybeans, and when used in the coinoculation with $B$. japonicum reduces it, but promotes an increase in nodule size, thus increasing its dry mass. These treatments also increased the activity of enzymes related to plant defense in V4 stage of culture, and reduced the photosynthetic rate of the plant. However, they showed yield per plant similar to treatments with mineral $\mathrm{N}$ and especially B. japonicum which is the recommended way of handling and currently used in Brazil. It has also been shown that the photosynthetic activity of the leaves in V4 stage interferes with the number of grains per pod, and the dry weight of root and aerial part exert primary role in crop yield. Also a negative correlation between stomatal conductance and the number of nodes in V4 should be further studied to demonstrate whether it is a possible way of regulating the activity nodule soybean plant was observed. And still the photosynthetic activity did not increase the plant's production, only interfered with components of production as the number of seeds per pod.

\section{Material and methods}

\section{Experimental design}

The experimental design was entirely randomized, with seven treatments and four repetitions, totaling 84 pots, 28 pots used for each evaluation, at stages V4, R4 and R9. The used treatments consisted in the absence, presence or association between diazotrophic bacteria and nitrogen fertilizer as recommended for the soybean crop: T1 - control (not 
inoculated seeds and without nitrogen fertilization); T2 fertilization with nitrogen $\left(240 \mathrm{Kg}\right.$ of $\left.\mathrm{N} \mathrm{ha}^{-1}\right)$; $\mathrm{T} 3$ inoculating seeds with Bradyrhizobium japonicum (Semias 5079 and 5080) without N; T4 - Azospirillum brasilense (AbV5+AbV6) without N; T5 - A. brasilense (AbV5+AbV6+AbV7) without $\mathrm{N}$; T6 - B. japonicum $+A$. brasilense (AbV5+AbV6) without fertilization $\mathrm{N}$; and $\mathrm{T} 7-B$. japonicum $+A$. brasilense (AbV5+AbV6+AbV7) without fertilization $\mathrm{N}$. In the treatments with inoculations, the same were carried out $30 \mathrm{~min}$ before sowing, mixed with the inoculant in the mass of seeds using a plastic bag and left in the shade until the time of sowing.

\section{Experimental management}

For inoculation the doses used were 60 grams of inoculant Simbiose $\operatorname{Nod}^{\circledR}$ B. japonicum (Semias 5079 and 5080, $5 \times$ $10^{9} \mathrm{CFU} \mathrm{g}^{-1}$ ) per $100 \mathrm{~kg}$ of seed. The same dosage was used for inoculation of $A$. brasilense (AbV5+AbV6) using the product Graminante ${ }^{\circledR}\left(3 \times 10^{9} \mathrm{CFU} \mathrm{mL}^{-1}\right)$, and A. brasilense (AbV5+AbV6+AbV7) using the product "AbV5+AbV6+

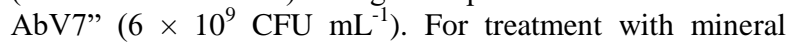
nitrogen, this was applied in installments, at the time of sowing (30\%) and the remainder in V2 stage of the soybean crop $(70 \%)$.

The crop was planted in a 12 liters pots, filled with substrate obtained from the horizon A of soil classified as Eutroferric RED LATOSOL with clayey texture (Embrapa, 2013). The chemical characteristics of the substrate were the following: $\mathrm{pH}\left(\mathrm{H}_{2} \mathrm{O}\right)$ : 5.00; $\mathrm{P}$ available (Mehlich): $11.78 \mathrm{mg}$ $\mathrm{dm}^{-3}$; K $\left(\right.$ Mehlich $\left.^{-1}\right): 0.26 \mathrm{cmol}_{\mathrm{c}} \mathrm{dm}^{-3} ; \mathrm{Ca}^{2+}\left(\mathrm{KCl} 1 \mathrm{~mol} \mathrm{~L}^{-1}\right)$ : $3.82 \mathrm{cmol}_{\mathrm{c}} \mathrm{dm}_{-3} ; \mathrm{Mg}^{2+}\left(\mathrm{KCl} 1 \mathrm{~mol} \mathrm{~L}^{-1}\right): 0.86 \mathrm{cmol}_{\mathrm{c}} \mathrm{dm}^{-3}$ and $\mathrm{Al}^{3+}\left(\mathrm{KCl} 1 \mathrm{~mol} \mathrm{~L}^{-1}\right): 0,10 \mathrm{cmol}_{\mathrm{c}} \mathrm{dm}^{-3} ; \mathrm{H}+\mathrm{Al}$ (calcium acetate $\left.0.5 \mathrm{~mol} \mathrm{~L}^{-1}\right): 4.92 \mathrm{cmol}_{\mathrm{c}} \mathrm{dm}^{-3}$; SB: $4.94 \mathrm{cmol}_{\mathrm{c}} \mathrm{dm}^{-3}$; V: $50.10 \%$, M.O.: $16.40 \mathrm{~g} \mathrm{dm}^{-3}$.

The soil correction was performed 30 days before sowing, rising base saturation to $70 \%$ (Embrapa, 2011), being the base of fertilization carried out according to recommendation for Brazil. At the time of sowing the substrate had population of $2 \times 10^{6} \mathrm{CFU} \mathrm{g}^{-1}$ diazotrophic bacteria.

The sowing was carried at a seeding depth $2.5 \mathrm{~cm}$. It was used the cultivar CD 250 distributing 10 seeds per pot and 10 days after emergence was carried out a thinning leaving only two plants per pot. The cultural treatments were performed as required, according to Embrapa (2011).

\section{Determination of biometric characteristics}

Ratings for the roots and aerial part were held in V4 and R4 stages, determining the number of nodules by counting, highlighting the roots after the plants were separated into roots and the aerial part and equipping process them in kraft paper bags, subsequently dried in an oven with forced air at $65^{\circ} \mathrm{C}$ for $72 \mathrm{~h}$, later performing weighing on a precision scale, thus determining the dry matter of roots and dry matter of nodules, dry matter of shoot and foliar, the relationship between the mass of the area known to the total dry mass of leaves.

\section{Determation of gas exchange}

The determination net assimilation rate of $\mathrm{CO}_{2}$ (A), transpiration (E) and stomatal conductance $\left(\mathrm{g}_{\mathrm{s}}\right)$ was performed in V4 stage and R4 using the IRGA LI-6400XT equipment (Licor Inc. Lincoln, NE). Readings were taken in the morning between 09:00 am and 11:00 am, on a fully sunny days, using fully developed leaflets belonging to photosynthetically active leaves and without injuries, located in the middle third of the plants. Reading was performed at two different leaves on each plant from the pot, resulting in four samples per pot. The average active photosynthetic photon flux on V4 and R4 stages during the determination of gas exchange were $1,300 \pm 15.97$ and $1,300 \pm 18.53 \mathrm{~m}^{-2} \mathrm{~s}^{-1}$ and the average concentration of $\mathrm{CO}_{2}$ in the atmosphere was $380 \pm 4.50$ and $375 \pm 1.98 \mathrm{~m}^{-2} \mathrm{~s}^{-1}$, respectively.

\section{Determination of enzymatic activity and chlorophyll}

For determination of enzymatic activity and chlorophyll content composite samples of leaflets fully expanded trifoliate leaves were collected, identified and packaged in aluminum foil, and stored immediately immersed in liquid nitrogen. The activity of peroxidase (POX) was determined at $30^{\circ} \mathrm{C}$, through direct spectrophotometric method (Hammerschmidt et al., 1982), while the phenylalanine ammonia-lyase activity (PAL) was determined according to the methodology described by Umesha (2006). The content of chlorophyll $a$ and $b$ was determined by the method of Sims and Gamon (2002), and reading the following wavelengths $663 \mathrm{~nm}$ (chlorophyll $a$ ) and $647 \mathrm{~nm}$ (chlorophyll $b$ ).

\section{Determination os soybean production}

At the time of grain maturation (R9 stage) was held manual harvest the pods, and given the number of pods per plant and the number of seeds per pod (20 pods randomly chosen within each plot). After the manual threshing pod the moisture grain was standardized to $13 \%$, determining the production and being expressed in grams per plant.

\section{Statistical analyses}

The data were submitted to analysis of variance at $\mathrm{p} \leq 0.05$ significance, and when significant Tukey test was applied to $5 \%$ error probability $(\mathrm{P} \leq 0.05)$, where relevant, with the help of Sisvar software (Ferreira, 2011) was also held the Pearson correlation among the studied variables.

\section{Conclusion}

The use of co-inoculation of B. japonicum + A. brasilense via seed reduces soybean nodulation, but the use of $\mathrm{AbV} 5+\mathrm{AbV} 6+\mathrm{AbV7}$ in isolation promotes increase in nodulation, from the natural soil population and increases the activity of enzymes in plant defense on soybeans in V4 stage, however reduces the photosynthetic activity. The increase in photosynthetic activity of the plant in V4 and R4 culminates in an increase in the number of grains per pod. The dry weight of root and aerial part have a direct role in the soy plant production in both the phenological stages evaluated, which justifies the use of bacteria promoters of plant growth co-inoculated in soybean. The use of nitrogen, B. japonicum, $\mathrm{AbV} 5+\mathrm{AbV} 6+\mathrm{AbV} 7$ and AbV5+AbV6+AbV7+B. japonicum provides the highest yields per plant. There is a negative correlation between nodulation and stomatal conductance of plants in V4, which may represent a form of control by the plant, requiring further study about this correlation.

\section{Acknowledgements}

To CAPES, the Araucaria Foundation supports scientific and technological development of Paraná, affiliated with State Secretary of Science, Technology and Higher Education SETI, CAPES / PNPD, the INCT-FBN for financial support 
and CNPq productivity scholarship granted by the researcher Dr. Vandeir Francisco Guimarães.

\section{References}

Almeida HO, Barbosa MO, Marques AE, Pereira THA, Magalhães Júnior MJ, Tessarollo NG, Games PD, Barros EG, Stolf-Moreira R, Marcelino-Guimarães FC, Abdelnoor RV, Pereira PRG, Baracat-Pereira MC (2012) Enzimas marcadoras de indução de resistência diferencialmente reguladas em soja resistente e suscetível à ferrugemasiática-da-soja. Pesq Agro Bras 47:163-172

Anollés CG (1997) Research molecular dissection and improvement of the nodule symbiosis in legumes. Field Crops Res 53:47-68

Araújo ASF, Teixeira GM, Campos AX, Silva FC, Ambrosano EJ, Trivelin PCO (2005) Utilização de nitrogênio pelo trigo cultivado em solo fertilizado com adubo verde (Crotalaria juncea) e/ou uréia. Ciên Rural 35:284-289

Araujo FF, Guaberto FM, Silva IS (2012) Bioprospecção de rizobactérias promotoras de crescimento em Brachiaria brizantha. Rev Bras Zootec 41:521-527

Bárbaro IM, Machado PC, Bárbaro Junior LS, Ticelli M, Miguel FB, Silva JÁ (2009) Produtividade da soja em resposta á inoculação padrão e co-Inoculação. Colloquium Agrariae 5:1-7

Baysal O, Soylu EM, Soylu S (2003) Induction of defencerelated enzymes and resistance by the plant activador acibenzolar-S-methyl in tomato seedlings against bacterial canker caused by Clavibacter michiganensis spp. Michiganensis. Plant Pathol 52:747-753

Bottini R, Fulchieri M, Pearce D, Pharis RP (1989) Identification of gibberellins $\mathrm{A} 1, \mathrm{~A} 3$ and iso-A 3 in cultures of Azospirillum lipoferum. Plant Physiol 90:45-47

Cacciari I, Lippi D, Pietrosanti T, Pietrosanti W (1989) Phytohormone-like substances produced by single and mixed diazotrophic cultures of Azospirillum and Arthrobacter. Plant Soil 115:151-153

Calbo MER, Moraes JAPV (1997) Fotossíntese, condutância estomática, transpiração e ajustamento osmótico de plantas de buriti submetidas a estresse hídrico. Rev Bras Fisio Veg 9:117-123

Cassán F, Perrig AP, Sgroya V, Masciarellia O, Pennab C, Lunaa V (2009) Azospirillum brasilense Az39 and Bradyrhizobium japonicum E109, inoculated singly or in combinati promote seed germination and early seedling growth in corn (Zea mays L.) and soybean (Glycine max L.). Eur J Soil Biol 45:28-35

Conab - Companhia Nacional de Abastecimento. Acompanhamento de safra brasileira: grãos, oitavo levantamento, maio 2014 / Companhia Nacional de Abastecimento. - Brasília: Conab, 2014.

Costa GF, Marenco RA (2007) Fotossíntese, condutância estomática e potencial hídrico em árvores jovens de andiroba (Carapa guianensis). Acta Amaz 37:229-234

Crozier A, Arruda P, Jasmim JM, Monteiro AM, Sandberg G (1988) Analysis of indole-3-acetic acid and related indóis in culture medium from Azospirillum lipoferum and Azospirillum brasilense. Appl Environ Microbiol 54:28332837

Dalchiavon FC, Carvalho MP (2012) Linear and spatial correlation of the yield componentes and soybean yield. Semina: Ciências Agrárias 33:541-552

Denison RF, Harter BL (1995) Nitrate effects on nodule oxygen permeability and leghemoglobin. Nodule oximetry and computer modeling. Plant Physiol 107:1355-1364
Didonet AD, Lima OS, Candaten AA, Rodrigues O (2000) Realocação de nitrogênio e de biomassa para os grãos, em trigo submetido a inoculação de Azospirillum. Pes Agro Bras 35:401-411

Embrapa (Empresa Brasileira de Pesquisa Agropecuária). 2013. Sistema brasileiro de classificação de solos. Embrapa - SPI/Embrapa - Solos. Brasília/Rio de Janeiro, BR.

Embrapa Soja. Tecnologias de produção de soja - região central do Brasil 2012 e 2013. Londrina: Embrapa Soja, 2011. $261 \mathrm{p}$

Fagan EB, Medeiros SLP, Manfron PA, Casaroli D, Simon J, Neto DD, Lier QJ, Santos OS, Müller L (2007) Fisiologia da fixação biológica do nitrogênio em soja - revisão. Rev FZVA 14:89-106

Fei H, Vessey JK (2004) Further investigation of the roles of auxin and cytokinin in the $\mathrm{NH}_{4}$ 1-induced stimulation of nodulation using white clover transformed with the auxinsensitive reporter GH3: gusA. Physiol Plant 12:674-681

Ferlini HÁ (2006) Co-inoculación en soja (Glicyne max) con Bradyrhizobium japonicum y Azospirillum brasilense. Santa Fé, Engormix, 6p

Ferreira DF (2011) Sisvar: um sistema computacional de análise estatística. Ciên Agrotec 35:1039-1042

Figueiredo MVB, Seldin L, Araujo FF (2010) Plant growth promoting rhizobacteria: fundamentals and applications In: Maheshwari DK (Ed.) Plant Growth and Health Promoting Bacteria.1.ed. Berlin: Springer-Verlag, 500p

Flores P, Fenoll J, Hellin P, Aparicio-Tejo P (2010) Isotopic evidence of significant assimilation of atmospheric-derived nitrogen fixed by Azospirillum brasilense co-inoculated with phosphate-solubilising Pantoea dispersa in pepper seedling. Appl Soil Ecol 46:335-340

Gerasimova NG, Pridvorova SM, Ozeretskovskaya OL (2005) Role of phenylalanine ammonia-lyase in the induced resistance and susceptibility of potato plants. Appl Biochem Microbiol 41:103-105

Hammerschmidt R, Nuckles EM, Kuc J (1982) Association of enhanced peroxidase activity with induced systemic resistance of cucumber to Colletotrichum lagenarium. Physiol Plant Pathol 20:73-82

Hungria M (2001) Fixação Biológica de Nitrogênio na cultura da soja. Londrina: Embrapa Soja. 48 p

Juge C, Prévost D, Bertrand A, Bipfubusa M, Chalifour FP (2012) Growth and biochemical responses of soybean to double and triple microbial associations with Bradyrhizobium, Azospirillum and arbuscular mycorrhizae. Appl Soil Ecol 61:147-157

Kaschuk G, Kuyper TW, Leffelaar PA, Hungria M, Giller KE (2009) Are the rates of photosynthesis stimulated by the carbon sink strength of rhizobial and arbuscular mycorrhizal symbioses? Soil Biol Biochem 41:1233-1244

Konrad MLF, Silva JAB, Furlani PR, Machado EC (2005) Trocas gasosas e fluorescência da clorofila em seis cultivares de cafeeiro sob estresse de alumínio. Bragantia 64:339-347

Lemos JM, Guimarães VF, Vendusculo ECG, Santos MF, Offemann LC (2013) Resposta de cultivares de trigo à inoculação de sementes com Azospirillum brasilense, e à adubação nitrogenada em cobertura. Científica 41:189-198

Marques AE, Games PD, Fontes PP, Barbosa MO (2012) Enzimas indicadoras do estado de indução de resistência em genótipos de soja submetidos à deficiência de potássio. Paper presented at VI Congresso Brasileiro de Soja, Cuiabá.

Oliveira AD, Fernandes EJ, Rodrigues TJD (2005) Condutância estomática como indicador de estresse hídrico em feijão. Eng Agríc 25:86-95 
Pedroza FO, Souza EM (2008) Instituto Nacional de Ciência e Tecnologia da Fixação Biológica de Nitrogênio em Gramíneas. Curitiba, 2008. 232p

Pereira AR (1989) Aspectos fisiológicos da produtividade vegetal. Rev Bras Fisio Veg 1:139-142

Plazinski J, Rolfe BG (1985) Influence of Azospirillum strains on the nodulation of clovers by Rhizobium strains. Appl Environ Microbiol 49:984-989

Quadros PD, Roesch LFW, Silva PRF, Vieira VM, Camargo FAO (2014) Desempenho agronômico a campa de híbridos de milho inoculados com Azospirillum. Rev Ceres 61:209218

Radwan TEE, Mohamed ZK, Reis VM (2004) Efeito da inoculação de Azospirillum e Herbaspirillum na produção de compostos indólicos em plântulas de milho e arroz. Pes Agro Bras 39:987-994

Reis Junior FB, Machado CTT, Machado AT, Sodek L (2008) Inoculação de Azospirillum amazonense em dois genótipos de milho sob diferentes; regimes de nitrogênio. Rev Bras Ciênc Solo 32:1139-1146

Rodrigues LFOS, Silva MB, Gonçalves EDV, Mattiello VD, Berté LN, Meinerz CC, Guimarães VF (2008) Trocas gasosas em milho inoculado com Azospirillum brasilenses e submetido ao déficit hídrico. Paper presented at XXIX CONGRESSO NACIONAL DE MILHO E SORGO, 2012, Águas de Lindóia, p 302-308, 2012

Santos MHR, Severo BB, Bittencourt JVM (2011) Avaliação do desempenho de inoculante à base de Bradyrhizobium japonicum na cultura de soja em duas diferentes regiões do
Paraná. Paper presented at III Ciclo de Atualização Agropecuária, p 32-37, 2011

Silva AF, Carvalho MAC, Schoninge EL, Monteiro S, Caione G, Santos PA (2011) Doses de inoculante e nitrogênio na semeadura da soja em área de primeiro cultivo. Biosci J 27:404-412

Sims DA, Gamon JA (2002) Relationships between leaf pigment content and spectral reflectance across a wide range of species, leaf structures and developmental stages. Remote Sens Envoron 81:337-354

Stephens BD, Neyra CA (1983) Nitrate and Nitrite reduction in relation to nitrogenase activity in soybean nodules and Rhizobium japonicum bacteroids. Plant Physiol 71:731-735

Taiz L, Zeiger E (2013) Fisiologia Vegetal. Porto Alegre: Artamed, 2013.918 p

Umesha S (2006) Phenylalanine ammonia lyase activity in tomato seedlings and its relationship to bacterial canker disease resistance. Phytoparsitica 34:68-71

Valadão FCA, Jakelaitis A, Conus LA, Borchartt L, Oliveira AA, Valadão Júnior DD (2009) Inoculação das sementes e adubações nitrogenadas e molíbdica do feijoeiro-comum, em Rolin de Moura, RO. Acta Amaz 39:741-748

Van Kessel C, Hartley C (2000) Agricultural management of grain legumes: has it led to an increase in nitrogen fixation. Field Crops Res 65:165-181

Whitmarsh J (2000) Electron transport and energy transduction In: Raghavendra AS (Ed), Photosynthesis: a comprehensive treatise. Cambrige University Press, Cambrige. 2000. p 83-107 